\title{
Computation of sediment transport in irrigation canals
}

\author{
H. M. CHAUDHRY, K. V. H. SMITH \& H. VIGIL
}

\section{Mr A. R. B. Edgecombe (M)}

The Authors are to be congratulated on their Paper. One has to have been engaged on similar investigations to appreciate the amount of work involved.

38. One of the channels dealt with silted up to such an extent that by 1963 it could only take $15100 \mathrm{cu}$. ft/s against a designed discharge of $22000 \mathrm{cu} . \mathrm{ft} / \mathrm{s}$. This is the Marala-Ravi Link Canal connecting the Chenab and the Ravi rivers which was constructed in 1956 for delivering supplies to the Sutlej Valley canals. It was designed for a discharge of $22000 \mathrm{cu}$. ft/s, bed width $345 \mathrm{ft}$, full supply depth 14.6 ft and a longitudinal grade of 1:10000 in the reach RDO to 249000 . The channel operates during summer when the supplies are surplus in the River Chenab at Marala.

39. In October 1961 the silt accumulation over five years (1956-61) in the first 40 miles of the Link was $252000000 \mathrm{cu}$. $\mathrm{ft}$, equivalent to an annual accumulation of $50400000 \mathrm{cu}$. ft. This volume of silt represented about $63 \%$ of the average annual silt load of the River Chenab at Marala of $78940000 \mathrm{cu}$. $\mathrm{ft}$, based on the area and location of the catchment.

40. This silting was expected. Prior to the construction of the Marala-Ravi Link, the design of the existing pocket and head regulator was successful in preventing silting of the Upper Chenab Canal of authorized, or designed, full supply discharge $13500 \mathrm{cu} . \mathrm{ft} / \mathrm{s}$. After the construction of the Link, it had to cope with a designed full supply discharge of $38500 \mathrm{cu}$. ft/s, i.e. Marala-Ravi Link, $22000 \mathrm{cu} . \mathrm{ft} / \mathrm{s}$ : UCC $16500 \mathrm{cu} . \mathrm{ft} / \mathrm{s}$. From Table 1 of the Paper it appears that the UCC was also silting up as the maximum discharge reported was only $14100 \mathrm{cu} . \mathrm{ft} / \mathrm{s}$ on $9 \mathrm{July}, 1963$. To overcome the difficulty two proposals were advanced:

(i) the remodelling of the existing Marala Headworks;

(ii) the construction of a new barrage some $1100 \mathrm{ft}$ downstream.

Proposal (ii) was adopted. Designs were completed in July 1964. Active construction work was undertaken in March 1965, and the barrage was substantially completed in September 1968.

41. 'As yet (1939) no determination has been made in India of the regime sill charge in a silt transporting channel-that such a regime charge exists, and that it is associated with regime equations so far developed, is fully recognized." ${ }^{8}$ This remains true as regards Pakistan. Spurred on by this Paper I have re-examined data which I collected on the North Western Canal in Sind. This is one of the three canals taking off from the Indus on the right bank at Sukkur, 480 miles downstream of Marala by river. The data are presented in Fig. 12.

42. The transportation of silt in a canal varies as the turbulence. Since Lacey's $f$, when equal to $3 V^{2} / 4 R$, is a measure of turbulence and eddying motion, may it not be possible to write $M=C f$, where $M$ is the regime silt charge in $\mathrm{g} / \mathrm{l}$ and $C$ a constant? From Fig. 12 it appears that the constant is 5.4 assuming $94 \%$ of the observed silt charge in the boil is the value of the charge at the mean velocity of the stream. How does this agree with the Authors' data?

43. It is of interest to compare the silt sizes of the Marala-Ravi Link with those of the North Western Canal shown in Fig. 12, not only of the canals but also in the river at the off-takes.

Paper published: Proc. Instn civ. Engrs, 1970, 45 (Jan.) 79-101. 


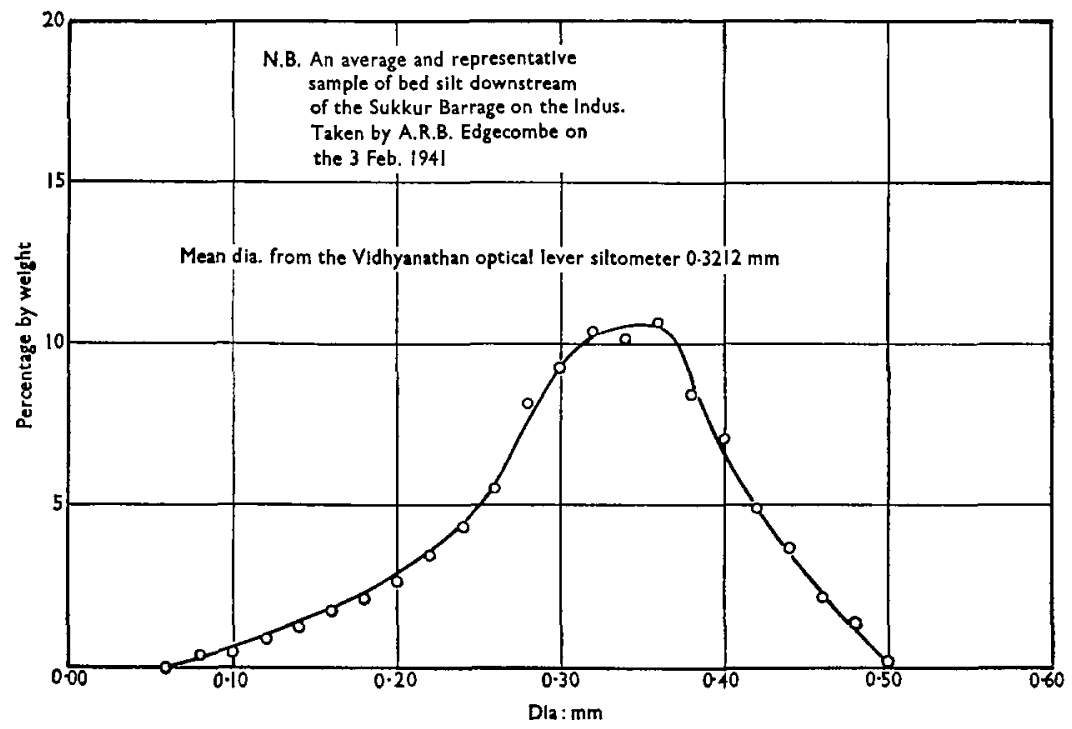

Fig. 12(a). Size distribution curve

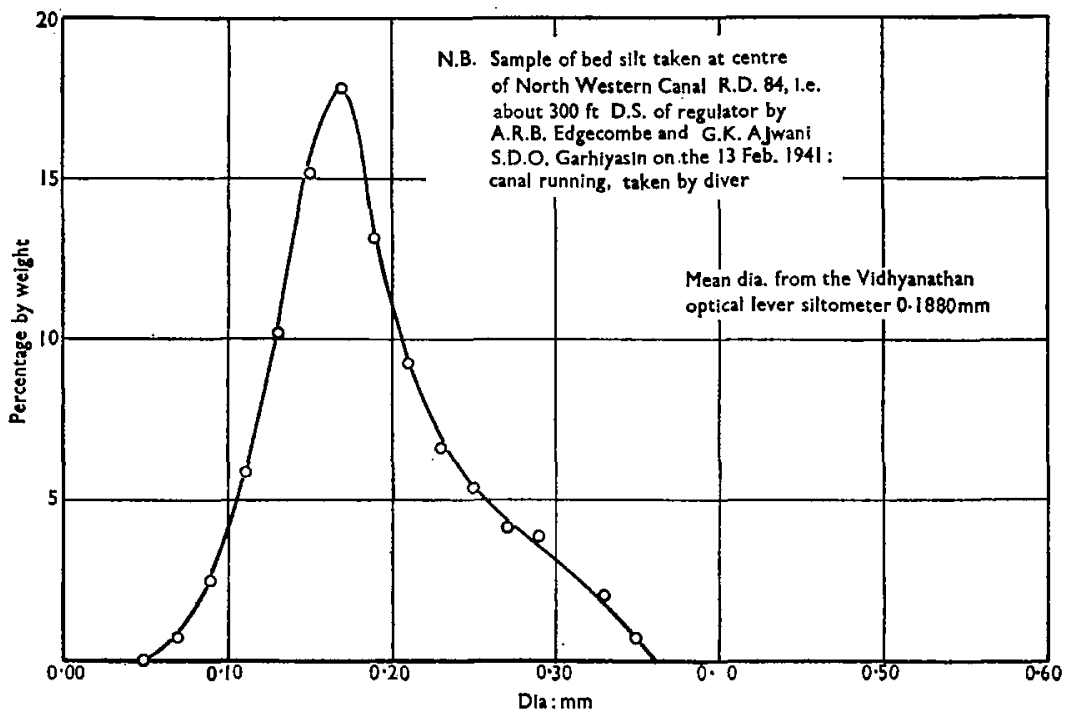

Fig. 12(b). Size distribution curve 
-

8 웅 \& 88 8 8 8

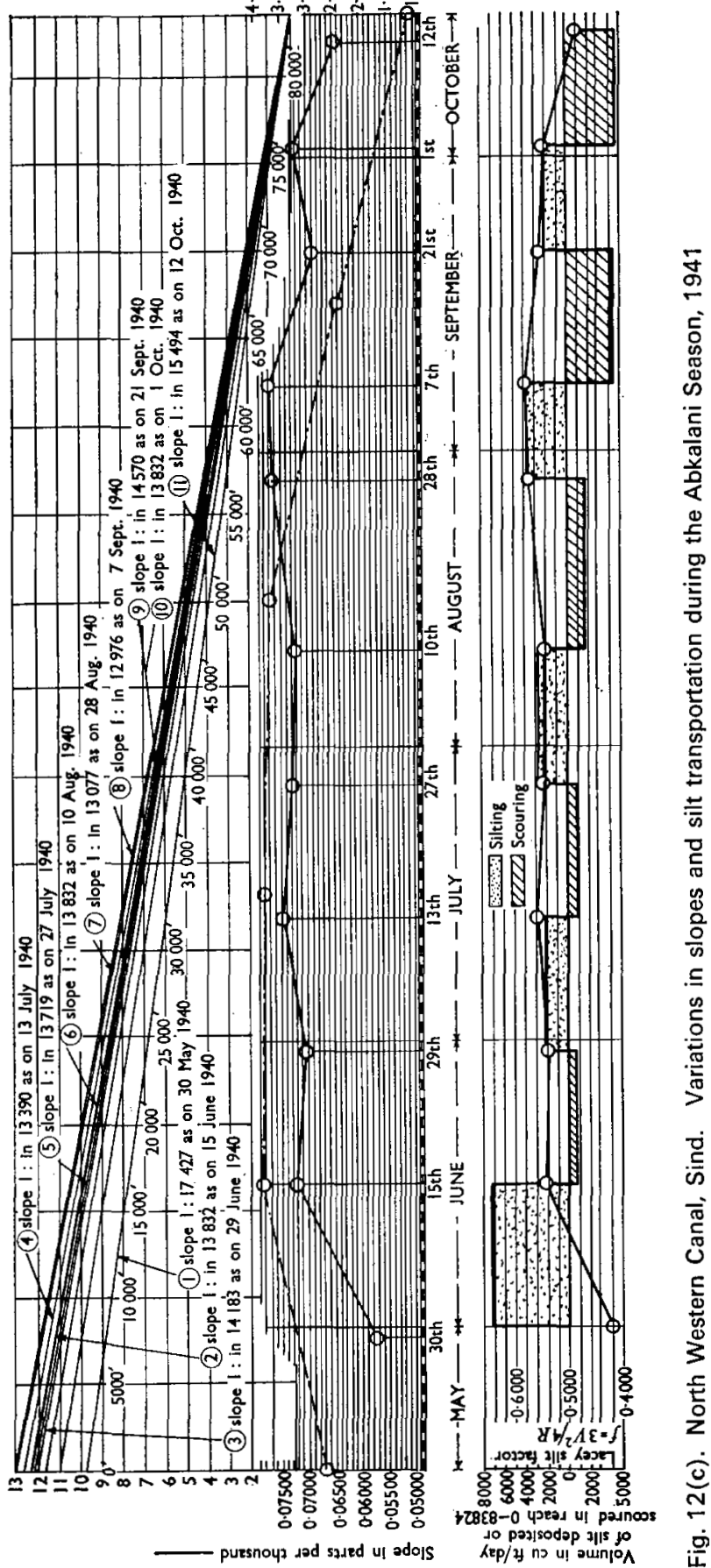




\section{Messrs Chaudhry, Smith and Vigil}

Mr Edgecombe's contribution makes a valuable addition to the Paper and the observations reported on the North Western Canal in Sind provide a useful demonstration of the occurrence of short term siltation and scour due to temporary imbalance between the sediment input at the headworks and the sediment transport capability of the flow. Although it has not been possible to make a detailed comparison because records of discharge were not given, it appears from Mr Edgecombe's observations that the quantity of silt deposited or scoured in the particular reach of the North Western Canal during the period of record was relatively small when compared with the quantity of silt entering the canal. The latter quantity, therefore, represents reasonably well the quantity of silt being transported by the flow.

45. Referring to Mr Edgecombe's diagram of the North Western Canal, the correlation between individual observations of the factor $f=3 V^{2} / 4 R$ and the corresponding quantity of silt entering the canal is remarkably good. Following on this comparison, if a reliable correlation could be achieved between the values of $f$ and the size and concentration of the sediment in a canal, a means would be available for assessing the sediment transport capability of the flow. So far as the Authors are aware, such a relationship has never been formulated with sufficient universality. Mr Edgecombe suggests that this relationship can be written $M=C f$, where $M$ is the regime silt charge in $\mathrm{g} / \mathbf{l}$ and $C$ is a constant. This is of course the same as $M=0.75 C V^{2} / R$, the equivalent of a sediment transport equation. The value of $C$ corresponding to the North Western Canal was 5.4 and the approximate value for the Upper Chenab Canal is $C=1 \cdot 5$. The lack of agreement between these values of $C$ is not very surprising when the complexity of most sediment transport equations is considered in relation to that quoted above.

46. Mr Edgecombe gives an interesting comparison between bed material grading in the river and in an off-taking canal, showing the mean diameter of the latter to be considerably finer. As compared with the North Western Canal, the median size of the Marala-Ravi Link bed material was probably slightly coarser (about $0.22 \mathrm{~mm}$ compared with $0.19 \mathrm{~mm}$ ). The comparison of river bed material gradings is difficult because of the wide variability of samples according to location and the particular time at which the sample was taken.

47. Referring back to Fig. 7 of the Paper, subsequent consideration has suggested that the amount of scour occurring in the Upper Chenab Canal between the head regulator and RD 105000 during the period April-May 1963 was appreciably overestimated. In the Paper, to avoid any suggestion of bias, the bed levels at the observation points were joined by straight lines, and scour or accretion estimated on that basis. However, it seems more probable that early deposition of sediment resulted in a sediment wave moving down the canal during the period of record. The result of such an interpretation of the bed levels at the widely separated observation points would be that the cumulative scour figures in column (iii) of Table 4 are considerably reduced. This results in an improvement in the comparison between the cumulative sediment inflow plus scour and the computed sediment outflow given in columns (iv) and (v) of Table 4.

48. The Authors are convinced that many alluvial canal stability problems are best solved by quantitative evaluation of the sediment transport capability of the flow, and comparison with sediment input on a long term basis. Accordingly, there seems a considerable advantage in using a method, such as the Colby method, which facilitates a quantitative approach.

\section{Reference}

8. LACEY L. Regime flow in incoherent alluvium. Central Board of Irrigation, Publication No. 20, Simla, 1939. 